\title{
Nurses and Staff Turnover Intentions in Private Hospitals
}

\author{
Ari Kuntardina \\ Doctoral Student of Management, Universitas Airlangga, Surabaya, Indonesia. \\ Sekolah Tinggi Ilmu Ekonomi Cendekia (STIEKIA) Bojonegoro \\ Indonesia \\ arikuntardina75@yahoo.com
}

\begin{abstract}
The purpose of this study is to examine the correlation of organizational justice, supervisor-employee relationship, and job satisfaction to nurse' turnover intentions in private hospitals. A survey study with a total of 152 nurses from two hospitals. Technique of taking data using closed questionnaire. Data analysis using structural equation modeling. Organizational justice and supervisor-employee relationship have direct effect on job satisfaction, and influence nurse's intentions turnover either directly or in regard to job satisfaction. The result can be used as a basis for decision making and future planning. The result also high light the need to emphasize on organizational justice and supervisor-employee relationship to enhance nurses' job satisfaction and to brainstrom solution to improve nurse's job satisfaction, which also to reduce nurses' turnover intentions.
\end{abstract}

Keyword : organizational justice, supervisor-employee relationship, job satisfaction, turnover intentions, nurse.

\section{INTRODUCTION}

Hospital is an institution providing health care service to the community. In providing public health services, hospitals require health professionals. The nurse is one of the health workers who provide health services to the community. There is a case of nurse recruitments for government hospitals which pose a problem to the private hospital. The nurse recruitment for government hospital will be followed by high turnover of nurses in private hospitals. Turnover is the cessation of an employee from work voluntarily or move from one workplace to another. While turnover intentions is defined by Glissmeyer, Bishop, and Fass (2008) in Yucel (2012) as a factor that mediates between the attitudes that affect the desire to quit of the work and actually quitting.

The reason why the turnover of nurses is important to learn, because nurses are the spearhead of service whom has direct contact with patients. The reducing number of nurses will also reduce the quality of treatment received by the patient. The quality of treatment will affect customers satisfaction towards hospital services. Besides, the increased costs associated with the cost of nurse recruitment, training, change of group cohesion, and the loss of tacid knowledge. Research that examine the causes of nurses turning over aims to gain a better understanding of the underlying issues and assist hospitals in lowering the level of turnover. In an effort to understand the problems of nurses turnover in hospitals, carried out through turnover intentions, rather than through actual turnover, because the actual turnover is more difficult to measure and turnover intentions is considered to represent the actual turnover (De Gieter et al., 2011).

In the initial study found dissatisfaction regarding share of income from shift work, Payroll, employment status, may affect the perception that they are being treated unfairly by hospital management. It leads to organizational justice. Nurses deal directly with supervisors in daily activities. Supervisors provide assignments, guidance, direction, motivation, appreciation, and reprimand in the execution of daily tasks. In regard to LMX theory, Subordinates in the "in-group" receive attention and high-quality relationships between supervisors and subordinates, rather than supervisor relationships with subordinates in "out-group". It leads to supervisor-employee relationship. Organizational justice and supervisor-employee relationship will be expected to affect the nurse's job satisfaction and ultimately affect the turnover intentions.

\section{LITERATURE REVIEW AND HYPOTHESIS}

Acording to Robbins and Judge $(2015 ; 143)$ organizational justice is how workers feel the authorities and decision makers in the workplace are treating them. Dimension of organizational justice are distributive justice, procedural justice, informational justice, interpersonal justice, and temporal justice. Distributive justice reflecting the perceived fairness of the decision-making result. Measurement of distributive justice by asking whether the decision result about such as pay, reward, evaluation, promotion, and job assignment is allocated with appropriate norms. Procedural justice, reflecting the perceived fairness of the decision-making process. Measurement of procedural justice through voice, correctability, consistency, bias suppression, accuracy rules. Interpersonal justice, reflects the perceived fairness of the treatment received by employees from the authorities. Measurement by respect rule and propriety rule. Informational justice reflects justice regarding the communication provided by the authorities to the nurses. Measurement by justification rule and truthfulness rule. Temporal justice dealing with justice in the distribution of time. Measured with personal time, marital time, office time or late sittings.

Adams's equity theory is a model of motivation that explains how people trying to get fairness and justice in social exchange or give-and-take relationships. This theory explains how an individual's motivation to behave in a certain way is forced by feeling of inequity or a lack of justice (Kreitner \& 
Kinicki, 2011;218). Two primary components are involved in the employee-employer exchange, inputs and outcomes. An employee's inputs are education/training, skills, creativity, seniority, age, personality traits, effort expended, and personal appearance. On the outcome side of exchange, organization provides such things as pay/bonuses, fringe benefits, challenging assignments, job security, promotions, status symbols, and participation in important decisions. It leads on hypothesis:

$\mathrm{H} 1$ :There is correlation between organizational justice with job satisfaction

H3 :There is correlation between organizational justice with turnover intentions

Supervisor-employee relationship is the degree of confidence, trust and respect the members have towards the leader. It is stated in the Fiedler's Contingency Model. Effective group performance depends on a compatibility between the leader style and most situations that give leadership control (Robin \& Judge, 2015;254). The underlying theory for supervisor-employee relationship is leader-member exchange (LMX) model. Kreitner and Kinicki $(2011 ; 489)$ said that leader-member exchange model of leadership about the development of dyadic relationships between manager and their direct reports, based on assumption that leader develope unique one to one relationships with each of the people reporting to them, such relationships are called vertical dyad. The forming of vertical dyad to be a naturally process, resulting from the leader attempt to delegate and assign work roles.

According to Greenberg and Baron (2008;511) leadermember exchange (LMX) model suggest that for various reasons leaders form different kinds of relationships with various groups of subordinates. The group that became the leader's favorite was called in-group. Members of in-groups receive considerably more attention from the leader and larger shares of resources they have to offer (such as time and recognition). The other group is called out-group, subordinates this group are disfavored by leaders. As such, they receive fewer valued resources from their leaders. Greenberg and Baron (2008;511) also states that according to the leadermember exchange (LMX) model, leaders distinguish between groups they favor (in-group) and those they do not favor (outgroups). Member of in-groups generally enjoy higher levels of morale, commitment, and job performance than members of out-groups. There is a possibility that in-group members are more satisfied with their jobs and more effective in performing them than out-group members. In-group members are also less likely to resign from their jobs than out-group members. Based on LMX theory, it is expected that high quality in relationship between nurse and supervisor will increase job satisfaction and decrease turnover intentions. It leads on hypothesis:

$\mathrm{H} 2$ : There is correlation between supervisor-employee relationship with job ssatisfaction

H4 : There is correlation between supervisor-employee relationship with turnover intentions

Organizational justice and turnover intententions allegedly affects the nurse's job satisfaction and ultimately the desire to leave the workplace. The higher organizational justice that nurse feels and the more effective the supervisor-employee relationship will increase the nurse's job satisfaction, and in the end will decrease the nurses intentions turnover. It leads on hypothesis,:

H5 : There is correlation between job satisfaction with turnover intentions

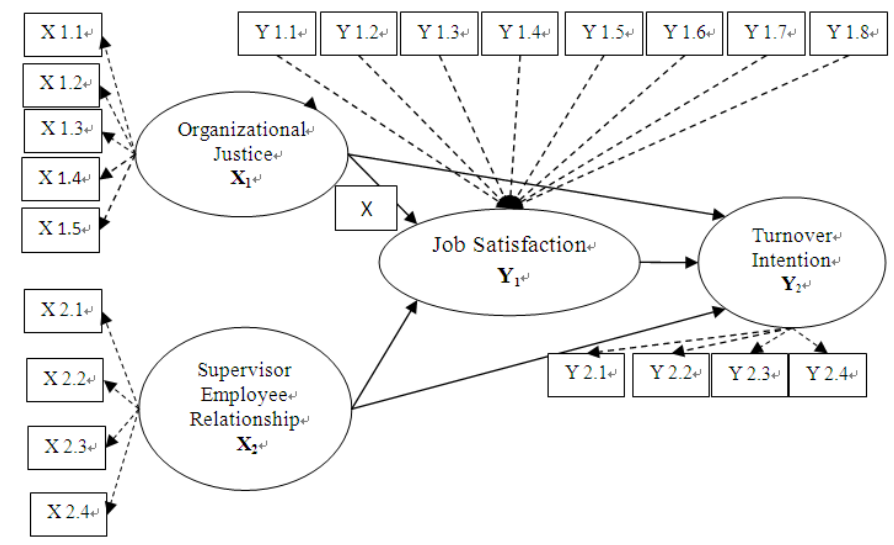

\section{RESEARCH METHODOLOGY}

This study was condacted in two hospitals located in the same demographic area in Bojonegoro, East Java. Data colected during the periode of march to december 2016. All nurses working in in these two institution were the target population. The total population 221 nurses. The questionnaire packages were sent to the nurse subjects through the hospitals' nursing departement. Subjects participated in this study voluntarily and anonymously. The number of samples collected is 152 .

Organizational justice measured with distributive justice, procedural justice, interpersonal justice, informational justice (Colquitt, Lepine \& Wesson,2013), and temporal justice (Usmani \& Jamal,2013). Supervisor-employee relationship measured with mutual trust, resiprocal influences, respect, sense of common fates (Kreitner \& Kinicki,2011). Job satisfaction measured with indirect working environment, direct working environment, salary and promotion, interaction with patient, working atmosphere, self growth, family support, challenge in work (Tzeng,2002). Turnover intentions measured with desire to quit work (Koslowsky,2012; Muliana,2013), thingking of quitting, search for alternative job (Negrin \& Tzafrir,2004), changes in career goals (Farris,1969; Raddaha,2012).

\section{RESULT}

\subsection{Validity test:}

The result of the research analysis on the validity test showed that the loading factor value on five organizational justice indicator (X1) was statistically significant in measuring organizational justice. The score of loading factor are 0.781 ; $0.832 ; 0.764 ; 0.862 ; 0735$. Four indicator of supervisoremployee relationship shows that can be used to measure supervisor-employee relationship (X2). The score of loading factor are $0.672 ; 0,686 ; 0.886 ; 0.813$. Job satisfaction 
measured by eight indicators. The score of loading factor are $0.627 ; 0.812 ; 0.819 ; 0.589 ; 0.596 ; 0.722 ; 0.556 ; 0.698$. Because all loading factor value is greater than 0.5 and $p<0.05$, then all the indikar can be used to measure job satisfaction. Turnover intentions measured by five indicators with score $0.691 ; 0,858 ; 0,770 ; 0,839 ; 0,734$.

\subsection{Reliability test}

Table 1.Reliability test

\begin{tabular}{|c|c|}
\hline Variables & CR \\
\hline Organizational justice (X1) & 0.896 \\
\hline $\begin{array}{c}\text { Supervisor-employee } \\
\text { relationship (X2) }\end{array}$ & 0.851 \\
\hline Job satisfaction & 0.850 \\
\hline Turnover intentions & 0.886 \\
\hline
\end{tabular}

Table 1 shows that all latent variables' value above the cut-off value of 0.7 , so they are reliable.

\subsection{Goodness of fit model}

Table 2. The result of Model testing

\begin{tabular}{|c|c|c|c|}
\hline Criteria & $\begin{array}{c}\text { Cut-off } \\
\text { value }\end{array}$ & $\begin{array}{c}\text { The calculation } \\
\text { results }\end{array}$ & $\begin{array}{c}\chi^{2} \text { and df }=378 \\
424.334 \\
\text { Good }\end{array}$ \\
\hline Chi - Square & $\begin{array}{c}\text { Expected } \\
\text { small }\end{array}$ & 421.092 & Good \\
\hline $\begin{array}{c}\text { Significance } \\
\text { Probability }\end{array}$ & $\geq 0,05$ & 0,062 & Good \\
\hline RMSEA & $\leq 0,08$ & 0,060 & Good \\
\hline GFI & $\geq 0,90$ & 0,919 & Good \\
\hline AGFI & $\geq 0,90$ & 0,905 & Good \\
\hline CMIN/DF & $\leq 2,00$ & 1,114 & Good \\
\hline TLI & $\geq 0,90$ & 0,952 & Good \\
\hline
\end{tabular}

Based on the table 2 above, the eight criteria of goodness of fit model used are good. Means there is a compatibility between the model and the data.

\subsection{Path coefficient test}

Table 3. Result of path coefficient test

\begin{tabular}{|l|c|c|c|c|}
\hline Variable & $\begin{array}{c}\text { Koefisie } \\
\text { n Jalur }\end{array}$ & $\begin{array}{c}\text { Critica } \\
\text { 1 Ratio } \\
\text { (C.R.) }\end{array}$ & $\begin{array}{c}\text { Probabilita } \\
\text { s } \\
\text { signifikans } \\
\text { i (P) }\end{array}$ & $\begin{array}{c}\text { Explanatio } \\
\mathrm{n}\end{array}$ \\
\hline $\begin{array}{l}\text { Organization } \\
\text { al justice } \rightarrow \\
\text { Job } \\
\text { satisfaction }\end{array}$ & 0.219 & 2.312 & 0.021 & Significant \\
\hline $\begin{array}{l}\text { Supervisor- } \\
\text { employee } \\
\text { relationship } \\
\rightarrow \text { Job }\end{array}$ & 0.410 & 3.924 & 0.000 & Significant \\
\hline
\end{tabular}

\begin{tabular}{|c|c|c|c|c|}
\hline satisfaction & & & & \\
\hline $\begin{array}{l}\text { Organization } \\
\text { al justice } \rightarrow \\
\text { Turnover } \\
\text { Intentions }\end{array}$ & -0.202 & -2.183 & 0.029 & Significant \\
\hline $\begin{array}{l}\text { Supervisor- } \\
\text { employee } \\
\text { relationship } \\
\rightarrow \text { Turnover } \\
\text { Intentions }\end{array}$ & -0.197 & $-1,985$ & 0.049 & Significant \\
\hline $\begin{array}{l}\text { Job } \\
\text { satisfaction } \\
\rightarrow \text { Turnover } \\
\text { intentions }\end{array}$ & -0.284 & -2.752 & 0.006 & Significant \\
\hline
\end{tabular}

Based on the results of data analysis it can be seen that organization justice have a positive and significant effect on job satisfaction. Organizational justice has a direct effect on job satisfaction of 0.219 , which means that any increase in organizational justice will increase the job satisfaction of 0.219. Supervisor-employee relationship has a positive and significant impact on job satisfaction

Table 4. Direct effects

\begin{tabular}{|c|c|c|c|}
\hline \multirow{2}{*}{\multicolumn{2}{|c|}{}} & \multicolumn{2}{c|}{ Endogenous Variable } \\
\cline { 2 - 4 } & $\begin{array}{c}\text { Job } \\
\text { satisfaction }\end{array}$ & $\begin{array}{c}\text { Turnover } \\
\text { intentions }\end{array}$ \\
\hline \multirow{4}{*}{$\begin{array}{c}\text { Exogenous } \\
\text { variables }\end{array}$} & $\begin{array}{c}\text { Organizational } \\
\text { Justice (X1) }\end{array}$ & 0.219 & -0.202 \\
\cline { 2 - 4 } & $\begin{array}{c}\text { Supervisor- } \\
\text { employee } \\
\text { relationship } \\
\text { (X2) }\end{array}$ & 0.410 & -0.197 \\
\cline { 2 - 4 } & $\begin{array}{c}\text { Job satisfaction } \\
\text { (Y1) }\end{array}$ & - & -0.284 \\
\hline
\end{tabular}

From table 4, we can see that supervisor-employee relationship gives the greatest direct effect on job satisfaction, and then job satisfaction on turnover intentions.

Table 5. Indirect effects

\begin{tabular}{|c|c|c|c|}
\hline \multirow{2}{*}{\multicolumn{2}{|c|}{ Indirect effects }} & \multicolumn{2}{|c|}{ Endogenous Variable } \\
\hline & & \multirow{2}{*}{$\begin{array}{c}\begin{array}{c}\text { Job } \\
\text { satisfaction }\end{array} \\
-\end{array}$} & \multirow{2}{*}{$\begin{array}{c}\begin{array}{c}\text { Turnover } \\
\text { intentions }\end{array} \\
-0.062\end{array}$} \\
\hline \multirow{3}{*}{$\begin{array}{c}\text { Exogenous } \\
\text { variables }\end{array}$} & $\begin{array}{c}\text { Organizational } \\
\text { Justice (X1) }\end{array}$ & & \\
\hline & $\begin{array}{l}\text { Supervisor- } \\
\text { employee } \\
\text { relationship } \\
\text { (X2) }\end{array}$ & - & -0.117 \\
\hline & $\begin{array}{c}\text { Job satisfaction } \\
\text { (Y1) }\end{array}$ & - & - \\
\hline
\end{tabular}


From table 5, we can see that job satisfaction gives an indirect effect from supervisor-employee relationship to turnover intentions in the amount of -0.117 . organizational justice also gives an indirect effect turnover intentions in the amount of -0.062 .

Table 6 . The total influence between research variables

\begin{tabular}{|c|c|c|c|}
\hline \multirow{2}{*}{ Total effects } & \multicolumn{2}{c|}{ Endogenous Variable } \\
\cline { 3 - 4 } & $\begin{array}{c}\text { Job } \\
\text { satisfaction }\end{array}$ & $\begin{array}{c}\text { Turnover } \\
\text { intentions }\end{array}$ \\
\hline \multirow{4}{*}{$\begin{array}{c}\text { Exogenous } \\
\text { variables }\end{array}$} & $\begin{array}{c}\text { Organizational } \\
\text { Justice (X1) }\end{array}$ & 0.219 & -0.265 \\
\cline { 2 - 4 } & $\begin{array}{c}\text { Supervisor- } \\
\text { employee } \\
\text { relationship } \\
\text { (X2) }\end{array}$ & 0.410 & -0.313 \\
\cline { 2 - 4 } & $\begin{array}{c}\text { Job satisfaction } \\
\text { (Y1) }\end{array}$ & - & -0.284 \\
\hline
\end{tabular}

From table 6, we can see that supervisor-employee relationship gives the greatest total effect on job satisfaction, and then on turnover intentions.

\section{DISCUSSION}

The purpose of this study was to identify variables predicting nurses' turnover intentions. Variables that predicted turnover intentions were job satisfaction, supervisor employee relationship, and organizational justice. From result of data analysis known that supervisor employee relationship gives the greates influence on nurses' job satisfaction and then on turnover intentions. It can be understood, because the role of supervisor is substantial for the nurses. Supervision in the context of nursing is the process of providing support to the resources that the nurse needs in order to complete the task. The more qualified the relationship between the nurses and their supervisor, the greater the supervisor's support for the resources to complete the task. A good supervision process also increase the knowledge and skills of subordinates, and reduced mistake at work. Therefore, increased supervisoremployee relationship will improve the nurse's job satisfaction. The results of this study are supported by Shacklock et al. (2012) which suggest that supervisor-nurse relationship will predict nurse job satisfaction. Also research from Stringer (2006) which states high quality leader-member exchange is related positively with job satisfaction. The increase in job satisfaction will reduce the nurse's turnover intentions. This is supported by Elanain (2014), who study LMX's influence on turnover intentions in United Arab Emirates (UAE), The results showed that LMX had an influence on employee's turnover intentions. Firth et al. (2004) found that emotional support from supervisors could mediate the effect of stressors on job satisfaction and tunover intentions of employees. The role of the supervisor is key to the strategic Human Resources Management in nursing department. Therefore, hospital management need to supervise the relationship between supervisors and subordinates, and supervisors should be selected, trained to create high quality supervisor-employee relationships.
Organizational justice is shown to affect the nurse's job satisfaction, and then decreases its turnover intentions. The perception of nurses in obtaining fair treatment from hospital management_ is considered as the authorities and decision makers_, will increase job satisfaction of nurse. The nursing organizational justice level will increase when nurse preferences are considered in the decision-making process (procedural justice), the results of a fair decision (distributive justice), treated with respect and dignity (interpersonal justice), hospital management provides honest information on the nurse (information justice), And justice in the distribution of time (temporal justice). The results of this study are supported by Abekah et al. (2013) where distributive justice, procedural justice, and interactional justice predict professional job satisfaction in the healthcare organization. While the influence of organizational justice on turnover intentions is supported by Owolabi (2012), organizational justice has a significant influence on turnover intentions on health workers at Ekiti State Nigeria.

Job satisfaction correlated with turnover intentions of nurses in private hospitals. This finding is supported by shield and ward research (2001); Tzeng (2002); De Gieter et al. (2011); Osuji et al. (2014); Raddaha et al. (2012). All dimensions of job satisfaction able to measure nurse's job satisfaction, so aspects that need to be considered to improve job satisfaction of nurses are indirect working environment, direct working environment, salary and promotion, interaction with patient, working atmosphere, self growth, family support, challenge in work. Raddaha et al. (2012) states that facet of job satisfaction which is give high satisfaction level to nurses is aspect of supervisor, co-workers, and nature of work. While contingent reward, fringe benefits and pay is the lowest satisfactory facets and strongly associated with nurse turnover. Organizational justice and supervisor-employee relationship have direct influence on turnover intentions, as well as indirect effect on turnover intentions through job satisfaction. So, there is partial mediation of the effect of organizational justice and supervisor-employee relationship on turnover intentions by job satisfaction.

\section{CONCLUSION}

Organizational justice and employee relationship supervisors have a direct effects on job satisfaction and turnover intentions. Organizational justice and employee relationship supervisors also have an indirect effect on turnover intentions through job satisfaction. Job satisfaction influences nurse intentions turnover. Supervisor-employee relationship gives the greatest total effect on job satisfaction, and then effect on turnover intentions.

\section{VII.PRACTICAL IMPLICATION}

The main problem expressed by nurses that participated in this study was the high level of nurses turnover in privat hospital. The result suggest that organizational justice and supervisor-employee relationship contributing to nurses job satisfaction and turnover intentions. Therefore, the mangement of hospital is advised to make an efforts to reduce turnover in a way to improve high quality of suprtvisor-employee relationship, supportive and empowering relationship between nurse supervisors and their nurses. The nurses will be more 
satisfied with their job when they experience high quality supervision and the same condition will also likely to encourage them to stay. Improving supervisors support is relatively inexpensive. Supervisors migh be encourage to have regular meeting with their subordinates to search what form of practical support from hospital management may help individuals perform better in their job. Supervisors also can be encourage to embrace high quality relationship will all employees, so there is no difference in manage of all employees. Therefore all nurses get to enjoy the benefits of favors such as mutual trust, support from their supervisor, effective comunication, consideration, and esteem.

Justice theory suggest participation in decision allows staff to influence outcomes that are important to them and affirms their statuse as valuated members of a group. The result of this study shows that all dimensionsions of organizational justice positevely correlated with job satisfaction. This is implied that job satisfaction depend directly on the level of organizational justice beeing perceived by the nurses. Therefore organizational justice is able to predict job satisfaction. Provides management with an increasing range of strategies to establish transparant management and decision processes participatory management. Strengthen a sense of organizational justice may benefit an organizational through enhancement of nurses job satisfaction and decrease turnover intentions.

\section{REFERENCES}

[1] Abekah-Nkrumah, G., \& Atinga, R., A. (2013). Exploring The Link Between Organizational Justice and Job Satisfaction and Performance in Ghanaian Hospital, Do demographic factors play a mediating role. Internationa Journal of Workplace Health Management Vol 6 (3). DOI: 10.1108/IJWHM-04-2011-0011.

[2] Colquitt, J. A., Lepine, J. A., \& Wesson, M., J. (2013). Organizational Behavior: Improving performance and commitment in the workplace. International Edition $\left(3^{\mathrm{td}}\right.$ ed.). New York: McGraw-Hill/Irwin companies Inc.

[3] De Gieter, S., Hofmans, J., \& Pepermans, R. (2011). Revisiting the impact of job satisfaction and organizational commitment on nurse turnover intention: An Individual differences analysis. International Journal of Nursing Studies 48, 1562-1569. DOI:10.1016/j.ijnurstu.2011.06.007.

[4] Elanain, Hossam M., A., (2014). Leader-Member Exchange and Intent to Turnover, Testing a mediatedeffects model in a high turnover work environment. Management Research Review vol. 37 (2), pp. 110-129. DOI:10.1108/MRR-09-2012-0197.

[5] Farris, George F., (1969). A Predictive Study of Turnover. Personnel Psychology 06/2008:24(2):311-328. DOI: 10.111/J.1744-6570.197tb02479x.

[6] Firth, L., Mellor, Moore, \& Loquet, C. (2003). How Can Managers Reduce Employee Intention to quit?. Journal of
Managerial Psychology, vol.19, No.2. DOI: 10.1108/02683940410526127.

[7] Greenberg, J. \& Baron, R. (2008). Behavior in Organizations $\left(9^{\text {th }}\right.$ ed.). New Jersey: Pearson Education.

[8] Kreitner, R., and Kinicki, A. (2011). Organizational Behavior, International Edition $\left(9^{\text {th }}\right.$ ed.). New York: McGraw-Hill/Irwin companies Inc.

[9] Koslowsky, M., Weisberg, J., Yaniv, E., \& ZaitmanSpeiser, I. (2012). Ease of Movement and Sector Affiliation as Moderators of The Organizational and Career Commitment, Turnover intentions link. Internationa Journal of Manpower vol. 33 (7), pp. 822839. DOI 10.1108/01437721211268348.

[10] Muliana, S. (2013). Faktor-Faktor yang Mempengaruhi Keinginan Pindah Kerja Perawat RS. Atmajaya. Tesis. Universitas Esa Unggul.

[11] Negrin and Tzakir (2004). Job Search Modes and Turnover. Career Development International; Vol. 9, No.5, pp.442-458. Emerald Group Publishing Limited 1362-0436. DOI: $10.1108 / 13620430410550727$

[12] Osuji, J., Uzoka, F., Aladi, F., and El-Husein, M. (2014). Understanding the Factors That Determine Registered Nurses' Turnover Intention. Research and Theory for Nursing Practice: An International Journal Vol. 28 (2).

[13]Owolabi A., B. (2012). "Effects of Organizational Justice and Organizational Environment on Turn-Over Intention of Health Workers in Ekiti State, Nigeria". Research in World Economy, 3(1).

[14] Robbins, S. P. dan Judge, T. A., (2015). Perilaku Organisasi Edisi Bahasa Indonesia. Jakarta: Salemba Empat.

[15]Raddaha,A., A et al. (2012). Jordanian Nurses' Job Satisfaction and Intention to Quit. Leadership in Health Sevices Vol. 25 No. 3 PP. 216-231. Doi $10.1108 / 17511871211247651$.

[16]Rizwan, M., \& Mukhtar, A. (2014). Preceding to Employee Satisfaction and Turnover Intention". International Journal $f$ Human Resource Studies Vol. 4 No. 3.

[17]Shields, M., and Ward, M., (2001). Improving nurse retention in the National Health Service in England: the impact of job satisfaction on intention to quite. Journal of Health Economics 20, 677-701. http://www.elsevier.com/PH:S0167-6296(01)000923/econbase.

[18] Shacklock K., Brunetto Y \& Wharton R. F. (2012). "The Impact of Supervisor-Nurse Relationship, Patient Role Clarity, and Autonomy Upon Job Satisfaction: Public and Private Sector Nurses". Journal of Mangement \& Organization, 18(5), 659-672.

[19]Stringer, L. (2006). The link Between the Quality of the Supervisor-Employee Relationship and the Level of the 
Employee's Job Satisfaction. Public Organize Rev, 6, 125-142. DOI: 10.1007/s11115-006-0005-0.

[20]Tzeng, H. M. (2002). The Influence of Nurses' working motivation and job satisfaction on intention to quit: An empirical investigation in Taiwan. International Journal of Nursing Studies 39, 867-878.

[21]Usmani, S., \& Jamal, S., (2013). Impact Distributive Justice, Procedural Justice, Interactional Justice, Temporal Justice, Spatial Justice on Job Satisfaction of
Banking Employees. Review of Integrative Business \&Economics Research vol. 2(1). www.sibresearch.org.

[22]Yucel, Ilhami (2012). “ Examining the relationship among job satisfaction, organizational commitment, and turnover intention: an empirical study. International journal of

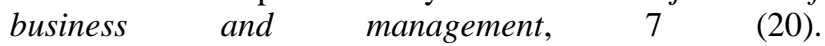
http://dx.doi.org.10.5539/ijbm.v7n20p44 